\title{
ANALISIS KOMPARASI BIAYA PENDIDIKAN ANTARA METODE TRADISIONAL DENGAN ACTIVITY BASED COSTING SYSTEM PADA MADRASAH DINIYAH AL-BURHANIYAH
}

\author{
1)Zulfia Hanum Alfi Syahr \\ 2)Ari Purwanti \\ 3)| Gusti Ketut Agung Ulupui \\ 1)Balitbang Diklat Kumdil MA RI, Jakarta, Indonesia \\ 2) Universitas Indonesia, Jakarta, Indonesia \\ 3)Universitas Udayana, Denpasar, Indonesia \\ e-Mail: qvia.alfisyahr@gmail.com
}

\begin{abstract}
The purpose of this study are describing how the cost of education per month in Madrasah Diniyah Al-Burhaniyah with the traditional method and the method of Activity Based Costing System $(A B C)$ and also showing the effectiveness and efficiency of management system in Madrasah Diniyah. In this study, the research object is the cost of education with the traditional method and the method of Activity Based Costing system (ABC) at Madrasah Diniyah Al-Burhaniyah in academic year of 2011/2012 until 2013/2014. The analysis used are quantitative analysis of the cost of education with the traditional method and the method of Activity based Costing System (ABC) and the analysis of the effectiveness and efficiency. Activities at Madrasah Diniyah Al-Burhaniyah can be grouped into two categories, namely, main activity and supporting activities. Costs arising from all of the activities is then calculated by the traditional method and the method of Activity Based Costing system $(A B C)$. The results of the calculation of the cost of education with the traditional method and the method of Activity Based Costing System (ABC) is mostly same. The effectiveness and efficiency management of the Madrasah Diniyah Al-Burhaniyah can be seen from learning service, facilities, costing system, and public participation. The traditional method is more appropriate to use in Madrasah Al-Burhaniyah Diniyah because the calculation steps are much simpler and the result is as same as the method of Activity Based Costing system $(A B C)$.
\end{abstract}

Keywords: activity based costing system, cost of education, Madrasah Diniyah.

\begin{abstract}
ABSTRAK
Tujuan penelitian ini adalah untuk mengetahui bagaimana biaya pendidikan per bulan di Madrasah Diniyah Al-Burhaniyah dengan metode tradisional dan metode Activity Based Costing system $(A B C)$ serta mengetahui keefektifan dan efisiensi dari pengelolaan Madrasah Diniyah. Pada penelitian ini yang menjadi objek penelitian adalah biaya pendidikan dengan metode tradisional dan metode Activity Based Costing system (ABC) pada Madrasah Diniyah Al-Burhaniyah pada tahun ajaran 2011/2012 hingga 2013/2014. Analisis yang digunakan adalah analisis kuantitatif untuk perhitungan biaya pendidikan dengan metode tradisional dan metode Activity based Costing system (ABC) serta analisis efektifitas dan efisiensi. Aktivitas pada Madrasah Diniyah Al-Burhaniyah dapat
\end{abstract}


dikelompokkan dalam dua kategori yaitu, aktivitas utama dan aktivitas penunjang. Biaya yang muncul dari semua aktivitas tersebut kemudian dihitung dengan metode tradisional dan metode Activity Based Costing system ( $A B C$ ). Hasil perhitungan biaya pendidikan dengan metode tradisional dan metode Activity Based Costing system( $A B C)$ hampir sama. Perhitungan tingkat efektifitas dan efisiensi dapat dilihat dari faktor, layanan belajar, saranaprasarana, pembiayan dan partisipasi masyarakat. Metode tradisional lebih tepat digunakan di Madrasah Diniyah Al-Burhaniyah karena langkah perhitungannya lebih sederhana dan hasilnya hampir sama dengan metode Activity Based Costing system (ABC).

Kata kunci: activity based costing system, biaya pendidikan, Madrasah Diniyah.

Sumber pendanaan Madrasah Diniyah yang berasal dari uang syariah siswa belum mampu menunjang kelengkapan sarana dan prasarana pendidikan di Madrasah Diniyah. Salah satu contohnya adalah keterbatasan gedung untuk kegiatan belajar, kurangnya buku penunjang pelajaran dan kurangnya tenaga guru yang ahli untuk mengajar di Madrasah Diniyah. Keterbatasan sarana dan prasarana inilah yang akhirnya mempengaruhi kualitas pelaksanaan pendidikan di Madrasah Diniyah. Rendahnya kualitas pendidikan di Madrasah Diniyah ini menyebabkan masyarakat menganggap kurang pentingnya mengikutsertakan anak-anak mereka untuk belajar agama di Madrasah Diniyah. Akibatnya, banyak peserta didik yang tidak menamatkan pendidikan mereka di Madrasah Diniyah dengan alasan ingin fokus pada sekolah formal.

Pendidikan yang baik tentu membutuhkan biaya yang tidak sedikit. Jadi kurang tepat jika ada istilah pendidikan harus murah bahkan gratis, tetapi yang manjadi masalah adalah apabila dana bantuan yang telah diberikan oleh pemerintah pusat ternyata tidak bisa mencukupi biaya operasional sekolah dan biaya lain yang diperlukan oleh sekolah, maka kekurangan biaya pendidikan pendidikan juga harus ditanggung oleh pemerintah daerah, orangtua/masyarakat secara proporsional.

Perhitungan biaya pendidikan ini diharapkan dapat membantu memperbaiki kualitas pendidikan di Madrasah Diniyah. Masyarakat dapat memiliki kepercayaan dan keyakinan untuk memotivasi putra-putrinya untuk belajar agama hingga lulus di Madrasah Diniyah. Selain itu juga untuk menambah akses informasi tentang pembiayaan pendidikan dan sistem pembiayaan dan perhitungannya di lembaga pendidikan luar sekolah khususnya studi kasus di Madrasah Diniyah karena dari penelusuran pustaka masih belum banyak penelitian yang mengambil topik analisis biaya pendidikan di Madrasah Diniyah.

Oleh sebab itu, melalui penelitian ini masalah yang dibahas adalah berapa biaya pendidikan per siswa per bulan yang dibutuhkan untuk melaksanakan pendidikan Agama Islam di Madrasah Diniyah dengan metode tradisional dan metode Activity Based Costing System (ABC). Serta menjelaskan tentang efektivitas dan efisiensi dari pengelolaan Madrasah Diniyah Al Burhaniyah. Tujuan yang ingin dicapai adalah memperoleh angka biaya pendidikan yang sesuai dalam arti mampu memberikan kontribusi untuk penyelenggaraan pendidikan Agama Islam yang berkualitas dan terjangkau oleh semua golongan masyarakat di Kecamatan Rembang, khususnya golongan menengah ke bawah.

Penentuan biaya pendidikan atau uang syariah per bulan per siswa pada metode tradisional dilakukan dengan menggunakan single pool, yaitu menjumlah semua pengeluaran lalu dibagi dengan jumlah siswa. Kelemahan dari single pool ini adalah kesulitan untuk menghilangkan item-item anggaran pengeluaran yang sudah tidak relevan lagi untuk digunakan sehingga menyebabkan 
ketidakakuratan dalam penentuan biaya, pembuatan keputusan, perencanaan, pengendalian dan pengelolaan Madrasah Diniyah.

Pada metode Activity Based Costing System $(A B C)$, terbentuknya biaya pendidikan disebabkan oleh adanya berbagai aktivitas untuk mendukung penyelenggaraan pendidikan Agama Islam di Madrasah Diniyah yang memicu dibutuhkannya sejumlah biaya. Aktivitas-aktivitas yang dilaksanakan di Madrasah Diniyah ada berbagai macam, antara lain aktivitas untuk siswa seperti, kegiatan belajar mengajar (KBM), pelaksanaan evaluasi, pelaporan rapor kepada wali murid, kegiatan ekstra kurikuler, peringatan hari besar Agama Islam, lomba-lomba. Aktivitas untuk guru, seperti rapat, seminar dan pelatihan serta aktivitas untuk pemeliharaan sarana prasarana. Berbagai aktivitas tersebut membutuhkan sejumlah dana tertentu untuk pelaksanaannya yang nantinya berpengaruh pada penentuan biaya pendidikan siswa di Madrasah Diniyah.

Beberapa penelitian tentang penerapan perhitungan biaya dengan pendekatan activity based costing (ABC) dalam bidang pendidikan salah satunya adalah Khrishnan (2006) yang mengembangkan model perhitungan biaya dengan pendekatan Activity Based Costing System (ABC) untuk memberikan informasi biaya yang lebih baik bagi pengambilan keputusan oleh manajemen universitas yang berguna untuk menentukan perencanaan strategis dan biaya yang lebih efektif untuk memenuhi kebutuhan konsumen di universitas. Di Indonesia, sistem Activity Based Costing System (ABC) telah pula diterapkan oleh Juanda dan Lestari (2012) yang meneliti tentang penentuan unit cost dari biaya pendidikan di Fakultas Kedokteran Universitas Muhammadiyah Malang.

Contoh lain penerapan metode $A B C$ di institusi pendidikan tinggi yaitu penelitian di suatu universitas negeri di Malaysia. Metode $A B C$ yang diterapkan di sini bertujuan untuk menentukan biaya pendidikan. Hasil penelitian menunjukkan biaya universitas untuk semua program pendidikan menjadi dasar perhitungan dan estimasi peningkatan biaya yang dapat memberikan informasi operasional yang lebih banyak yang berguna untuk penentuan keputusan strategis (Amizawati et.al, 2012).

Penerapan metode $\mathrm{ABC}$ selain mampu menentukan biaya pendidikan yang tepat juga bermanfaat untuk memberikan gambaran kualitas dari suatu institusi penyelenggara pendidikan. Penelitian tentang hubungan biaya dan kualitas suatu pendidikan tinggi menjelaskan bahwa biaya mampu memberikan penilaian kualitas apakah institusi pendidikan tersebut telah berjalan dengan baik atau tidak. Selain itu juga mampu mengidentifikasi apakah perubahan yang dilakukan oleh suatu institusi mampu memberikan kemajuan atau tidak (Ruhupatty dan Maguad, 2012).

Biaya satuan di tingkat sekolah merupakan kumpulan biaya pendidikan tingkat sekolah baik yang bersumber dari pemerintah, orang tua, dan masyarakat, yang dikeluarkan untuk menyelenggarakan pendidikan dalam satu tahun pelajaran (Prasetyo, 2012). Biaya satuan per murid merupakan ukuran yang menggambarkan seberapa besar uang yang dialokasikan sekolah secara efektif untuk kepentingan murid dalam menempuh pendidikan. Jenis-jenis biaya pendidikan sesuai dengan PP Nomor 48 Tahun 2008 (Badan Standar Nasional, 2006) tersebut dapat dibagi menjadi 3 jenis, yaitu Biaya Satuan Pendidikan, Biaya Penyelenggaraan dan/atau Pengelolaan Pendidikan, serta Biaya Pribadi Peserta Didik.

Metode penentuan biaya pendidikan secara tradisional dilakukan dengan menganalisis biaya total (total cost)dalam suatu lembaga pendidikan. Biaya total merupakan gabungan-gabungan biaya per komponen input pendidikan di tiap sekolah. Satuan biaya pendidikan merupakan biaya rata-rata yang dikeluarkan untuk melaksanakan pendidikan di sekolah per siswa per tahun anggaran. Satuan biaya ini merupakan fungsi dari besarnya pengeluaran sekolah serta banyaknya murid sekolah. 
Dengan demikian, satuan biaya ini dapat diketahui dengan jalan membagi seluruh jumlah pengeluaran sekolah setiap tahun dengan jumlah murid sekolah pada tahun yang bersangkutan.

Metode Activity Based Costing System adalah salah satu metode yang digunakan dalam menghitung biaya berdasarkan aktivitas yang dilakukan dalam organisasi. Perhitungan yang dihasilkan akan bermanfaat bagi manajemen untuk menelusuri keterangan mengenai aktivitas apa saja yang diperlukan dan yang tidak diperlukan lembaga dalam proses penyelenggaraannya. Dalam penerapannya, metode ABC dapat dilakukan melalui tiga tahap kegiatan (Blocher et.al, 2011) yaitu:

1. Tahap Pertama. Mengidentifikasi biaya sumber daya dan aktifitas. Analisis aktifitas ini merupakan kumpulan data dari dokumen, laporan dan catatan yang ada berkaian dengan aktifitas apa saja yang dilakukan untuk menjalankan kegiatan operasional organisasinya. Kemudian melakukan pengumpulan biaya dalam cost pool yang memiliki aktifitas yang sejenis atau homogen, terdiri dari dua langkah yaitu mengidentifikasi dan menggolongkan biaya kedalam berbagai aktifitas dan mengklasifikasikan aktifitas biaya kedalam berbagai aktifitas, pada langkah ini biaya digolongkan kedalam aktivitas yang terdiri dari 4 kategori yaitu: unit, batch, produk dan fasilitas.

2. Tahap Kedua. Membebankan biaya sumber daya pada aktifitas. Perhitungan biaya berdasarkan aktivitas ini menggunakan cost driver untuk konsumsi sumber daya yang membebankan biaya sumber daya ke aktivitas. Sehingga, harus ditentukan terlebih dahulu cost driver yang digunakan untuk konsumsi sumber daya berdasarkan hubungan sebab akibat. Biaya sumber daya dapat dibebankan ke aktivitas dengan menelusuri secara langsung atau dengan mengestimasi. Misalnya, listrik yang dipakai suatu kantor dapat ditelusuri secara langsung dengan melihat KWH meter yang ada. Jika penelusuran langsung tidak dapat dilakukan maka manajer dapat mengestimasi jumlah atau persentase usaha yang dilakukan karyawan pada setiap aktivitas yang diidentifikasi.

3. Tahap Ketiga. Membebankan biaya aktifitas ke objek biaya. Pada tahap terakhir ini membebankan biaya aktivitas ke objek biaya berdasarkan penggerak biaya untuk konsumsi aktivitas yang tepat. Outputnya adalah objek biaya untuk aktivitas yang dilakukan oleh perusahaan atau organisasi. Pada umumnya output dari sistem biaya ini adalah produk dan jasa.

Salah satu alat pengukuran kinerja yang dapat digunakan untuk mengukur efisiensi, dan efektifitas segala kegiatan pada organisasi sektor publik seperti yayasan Madrasah Diniyah adalah value for money (Mardiasmo, 2005). Value for money merupakan tolak ukur dalam anggaran belanja suatu organisasi, baik organisasi yang berusaha untuk mendapatkan laba (swasta) atau perusahan yang nonprofit seperti organisasi sektor publik. Pengukuran efisiensi pada value for money merupakan tercapainya output yang maksimum dengan input tertentu dengan kata lain merupakan perbandingan output/input yang dikaitkan dengan standar kinerja yang telah ditetapkan. Efektifitas menggambarkan tingkat pencapaian hasil program dengan target yang ditetapkan. Secara sederhana efektifitas merupakan perbandingan outcome dengan output.

\section{METODE}

Desain penelitian yang akan digunakan adalah penelitian dengan metode deskriptif. Instrumen penelitian yang akan digunakan adalah daftar pertanyaan wawancara yang diajukan kepada perwakilan pengurus Madrasah Diniyah. Pada penelitian ini yang menjadi data primer adalah data hasil wawancara dengan sumber datanya adalah responden perwakilan dari Madrasah Diniyah Al Burhaniyah. Data sekunder dari penelitian ini adalah data keuangan Madrasah Diniyah Al 
Burhaniyah Tahun 2011/2012 hingga 2013/2014. Sumber datanya adalah arsip laporan keuangan Madrasah Diniyah Al Burhaniyah. Pada penelitian ini analisis data yang dilakukan adalah,

1. Analisis kuantitatif penentuan biaya metode tradisional dan metode $A B C$.

a. Perhitungan biaya dengan metode tradisional

Biaya pendidikan per tahun = biaya operasional/ jumlah siswa

b. Perhitungan biaya dengan metode $A B C$

1) Mengidentifikasi aktivitas yang memicu biaya pada Madrasah Diniyah Al Burhaniyah dengan cara:

a) Mengumpulkan data mengenai laporan biaya pengajaran. Dalam tahap ini yang dimaksud dengan laporan biaya pengajaran adalah biaya honor guru, biaya evaluasi, biaya sarana prasarana, dan biaya lain yang berkaitan dengan pelaksanaan proses belajar.

b) Mengelompokkan biaya-biaya aktivitas akademik. Aktivitas akademik ini seperti kegiatan belajar, pelaksanaan evaluasi dan kegiatan lomba-lomba. Aktivitas tersebut kemudian dikelompokkan ke dalam aktivitas utama dan aktivitas penunjang.

c) Mengelompokkan aktivitas tersebut ke dalam biaya tetap dan tidak tetap.

2) Menghitung biaya penyelenggaraan secara total:

a) Menghitung jumlah elemen biaya pada setiap aktivitas

b) Menghitung costdriver dengan pembebanan biaya berdasarkan penelusuran langsung ataupun dengan alokasi perkiraan

c) Menghitung jumlah keseluruhan biaya yang akan dibebankan tersebut.

3) Menentukan biaya pendidikan per bulan sebagai cost object dengan membagi total biaya yang dibebankan tadi dengan jumlah siswa.

2. Analisis efektifitas dan efisiensi hasil penentuan biaya pendidikan di Madrasah Diniyah Al Burhaniyah berdasarkan metode tradisional dan metode ABC.

a. Tingkat efektifitas

Tingkat efektifitas $=($ realisasi penerimaan/target penerimaan $) \times 100 \%$

b. Tingkat efisiensi

Tingkat efisiensi $=($ keluaran riil/anggaran $) \times 100 \%$

\section{HASIL DAN PEMBAHASAN}

Tabel 1. Pengeluaran Madrasah Diniyah Al Burhaniyah Tahun 2011/2012.

\begin{tabular}{|c|c|}
\hline Jenis Pengeluaran & Jumlah \\
\hline Honor guru & Rp. 13.756 .000 \\
\hline Perawatan sarana prasarana & Rp. $\quad 1.497 .500$ \\
\hline Administrasi kelas & 306.500 \\
\hline Biaya sosial & 100.000 \\
\hline Biaya evaluasi dan laporan & 55.000 \\
\hline Biaya listrik & 50.000 \\
\hline Biaya telepon & - \\
\hline Biaya rapat & 260.000 \\
\hline Biaya kegiatan & Rp. 2.471 .000 \\
\hline Administrasi madrasah & - \\
\hline Jumlah & Rp. 9.396 .000 \\
\hline
\end{tabular}


Penentuan biaya pendidikan di Madrasah Diniyah dengan metode tradisional dilakukan dengan memfokuskan pada single pool. Single pool artinya, penentuan biaya satuan pendidikan hanya didasarkan pada jumlah pengeluaran yang dibagi dengan jumlah siswa. Jumlah pengeluaran di Madrasah Diniyah Al Burhaniyah dapat dilihat pada Tabel 1.

Tabel 2. Pengeluaran Madrasah Diniyah Al Burhaniyah Tahun 2012/2013.

\begin{tabular}{lrr}
\hline \multicolumn{1}{c}{ Jenis Pengeluaran } & \multicolumn{2}{c}{ Jumlah } \\
\hline Honor guru & Rp. & 22.435 .000 \\
Perawatan sarana prasarana & Rp. & 1.294 .000 \\
Administrasi kelas & Rp. & 223.500 \\
Biaya sosial & Rp. & 760.000 \\
Biaya evaluasi dan laporan & Rp. & 1.098 .000 \\
Biaya listrik & Rp. & 100.000 \\
Biaya telepon & & - \\
Biaya rapat & Rp. & 1.722 .000 \\
Biaya kegiatan & Rp. & 2.250 .100 \\
Administrasi madrasah & Rp. & 500.000 \\
\hline Jumlah & Rp. & 30.382 .600 \\
\hline Sumber : Laporan keuangan Madrasah AL-Burhaniyah 2012/2013 & \multicolumn{3}{c}{}
\end{tabular}

Tabel 3. Pengeluaran Madrasah Diniyah Al Burhaniyah Tahun 2013/2014.

\begin{tabular}{lrr}
\hline \multicolumn{1}{c}{ Jenis Pengeluaran } & \multicolumn{2}{c}{ Jumlah } \\
\hline Biaya honor guru & Rp. & 20.845 .000 \\
Perawatan sarana prasarana & Rp. & 2.142 .000 \\
Administrasi kelas & Rp. & 474.500 \\
Biaya sosial & Rp. & 780.000 \\
Evaluasi dan laporan & Rp. & 1.561 .500 \\
Biaya listrik & Rp. & 50.000 \\
Biaya telepon & Rp. & 50.000 \\
Biaya rapat & Rp. & 213.000 \\
Biaya kegiatan & Rp. & 2.698 .000 \\
Biaya administrasi madrasah & Rp. & 295.000 \\
\hline Jumlah & Rp. 29.109 .000 \\
\hline Sumber : Laporan keuangan Madrasah AL-Burhaniyah 2013/2014 & \multicolumn{2}{l}{}
\end{tabular}

Jenis pengeluaran di Madrasah Diniyah Al Burhaniyah ini dapat dikelompokkan ke dalam sepuluh macam biaya yaitu,honor guru, biaya perawatan sarana prasarana, administrasi kelas, sosial, evaluasi dan laporan, listrik, telepon, kegiatan, rapat dan biaya administrasi madrasah. Setelah diperoleh jumlah pengeluaran, maka dapat dihitung dengan metode tradisional biaya pendidikan selama satu tahun untuk setiap siswa. Perhitungan biaya pendidikan dengan metode tradisional ini dapat dilihat pada Tabel 4.

Tabel 4. Penentuan Tarif Uang Syariah Dengan Metode Tradisional pada Madrasah Diniyah Al Burhaniyah Tahun 2011/2012.

\begin{tabular}{cccccc}
\hline $\begin{array}{c}\text { Total } \\
\text { pengeluaran }\end{array}$ & $\begin{array}{c}\text { Jumlah } \\
\text { siswa }\end{array}$ & $\begin{array}{c}\text { Tarif biaya/ } \\
\text { tahun }\end{array}$ & $\begin{array}{c}\text { Tarif biaya/ } \\
\text { bulan }\end{array}$ & $\begin{array}{c}\text { Tarif biaya yang } \\
\text { dibebankan }\end{array}$ & Selisih \\
\hline Rp.19.396.000 & 162 & Rp. 119.728 & Rp. 9.977 & Rp. 10.000 & Rp. 23 \\
\hline
\end{tabular}


Tabel 5. Penentuan Tarif Uang Syariah Dengan Metode Tradisional pada Madrasah Diniyah Al Burhaniyah Tahun 2012/2013.

\begin{tabular}{cccccc}
\hline $\begin{array}{c}\text { Total } \\
\text { pengeluaran }\end{array}$ & $\begin{array}{c}\text { Jumlah } \\
\text { siswa }\end{array}$ & $\begin{array}{c}\text { Tarif biaya/ } \\
\text { tahun }\end{array}$ & $\begin{array}{c}\text { Tarif biaya/ } \\
\text { bulan }\end{array}$ & $\begin{array}{c}\text { Tarif biaya yang } \\
\text { dibebankan }\end{array}$ & Selisih \\
\hline Rp. 0.382 .600 & 174 & Rp. 174.613 & Rp. 14.551 & Rp. 15.000 & Rp. 449 \\
\hline
\end{tabular}

Tabel 6. Penentuan Tarif Uang Syariah Dengan Metode Tradisional pada Madrasah Diniyah Al Burhaniyah Tahun 2013/2014.

\begin{tabular}{cccccc}
\hline $\begin{array}{c}\text { Total } \\
\text { pengeluaran }\end{array}$ & $\begin{array}{c}\text { Jumlah } \\
\text { siswa }\end{array}$ & $\begin{array}{c}\text { Tarif biaya/ } \\
\text { tahun }\end{array}$ & $\begin{array}{c}\text { Tarif biayal } \\
\text { bulan }\end{array}$ & $\begin{array}{c}\text { Tarif biaya yang } \\
\text { dibebankan }\end{array}$ & Selisih \\
\hline Rp. 29.109.000 & 170 & Rp. 171.229 & Rp.14.269 & Rp.15.000 & Rp. 731 \\
\hline
\end{tabular}

Selisih kelebihan biaya pendidikan per siswa per bulan pada setiap tahun ajaran digunakan oleh Madrasah Diniyah sebagai dana cadangan. Dana cadangan ini disiapkan untuk mengantisipasi jika ada siswa yang menunggak uang syariah setiap bulannya. Selain itu juga untuk mengantisipasi libur panjang sebelum masuk tahun ajaran baru. Dana cadangan tersebut dimanfaatkan untuk membiayai kegiatan-kegiatan yang ada di akhir tahun ajaran tersebut. Selain itu, juga dapat digunakan untuk pengembangan Madrasah, misalnya dengan pengadaan peralatan penunjang kegiatan belajar.

Penentuan biaya pendidikan dengan metode Activity Based Costing System dilakukan dengan terlebih dahulu mengetahui aktivitas-aktivitas apa saja yang dilakukan dalam penyelenggaraan pendidikan Agama islam di Madrasah Diniyah Al Burhaniyah. Dari hasil wawancara diperoleh informasi aktivitas layanan pendidikan yang dilaksanakan oleh Madrasah Diniyah Al Burhaniyah. Aktivitas layanan pendidikan tersebut seperti disampaikan oleh informan mencakup aktivitas kurikulum, dan kegiatan kesiswaan. Aktivitas-aktivitas tersebut secara umum dapat diklasifikasikan menjadi dua kelompok pusat aktivitas, yaitu aktivitas utama dan aktivitas penunjang.

Berdasarkan aktivitas yang dilakukan oleh Madrasah Diniyah Al Burhaniyah pengelompokan elemen biaya sesuai dengan pusat aktivitas dirangkum dan disajikan dalam Tabel 7.

Tabel 7. Klasifikasi Pusat Aktivitas dan Elemen Biaya Operasional

\begin{tabular}{ll}
\hline \multicolumn{1}{c}{ Aktivitas Utama } & \multicolumn{1}{c}{ Aktivitas Penunjang } \\
\hline Biaya honor guru & Biaya perawatan sarana prasarana \\
Biaya evaluasi dan laporan & Biaya administrasi kelas \\
Biaya kegiatan & Biaya sosial \\
Biaya rapat & Biaya listrik \\
& Biaya telepon \\
& Biaya administrasi madrasah \\
\hline
\end{tabular}

Setelah aktivitas dan elemen biaya diidentifikasi, selanjutnya dilakukan pembebanan biaya yang dapat dilakukan dengan metode penelusuran langsung (direct tracing), penelusuran penggerak (driver tracing) dan alokasi. Berikut adalah tabel pembebanan sumber daya ke dalam aktivitasaktivitas yang ada di Madrasah Diniyah Al Burhaniyah. 
Tabel 8. Pembebanan Sumber Daya Ke Dalam Aktivitas

\begin{tabular}{lll}
\hline \multicolumn{1}{c}{ Jenis Aktivitas } & \multicolumn{1}{c}{ Dasar Alokasi } & \multicolumn{1}{c}{ Cost Driver } \\
\hline Biaya honor guru & Direct tracing & Jam mengajar \\
Perawatan sarana prasarana & Alokasi dengan perkiraan & Jumlah gedung \\
Administrasi kelas & Alokasi dengan perkiraan & Jumlah kelas \\
Biaya sosial & Alokasi dengan perkiraan & Jumlah pembayaran/ tahun \\
Kegiatan evaluasi dan laporan & Alokasi dengan perkiraan & Jumlah siswa \\
Biaya listrik & Direct tracing & KWH \\
Biaya telepon & Direct tracing & Menit \\
Biaya rapat & Alokasi dengan perkiraan & Jumlah pembayaran/ tahun \\
Biaya kegiatan & Alokasi dengan perkiraan & Jumlah pembayaran/ tahun \\
Biaya administrasi madrasah & Alokasi dengan perkiraan & Jumlah pembayaran/ tahun \\
\hline Sumber : Laporan Keuangan Madrasah Diniyah Al Burhaniyah Tahun 2013/2014 &
\end{tabular}

Dari Tabel 8 , berbagai aktivitas yang ada di Madrasah Diniyah Al Burhaniyah dialokasikan berdasarkan alokasi dengan perkiraan yang dihitung dengan menentukan prosentase jenis biaya yang dikeluarkan dibagi jumlah penerimaan. Penerimaan Madrasah Diniyah Al Burhaniyah diperlihatkan pada Tabel 9.

Tabel 9. Penerimaan Madrasah Diniyah Al Burhaniyah Tahun 2011/2012

\begin{tabular}{|c|c|}
\hline Bulan & Penerimaan \\
\hline September 2011 & Rp. $\quad 3.089 .500$ \\
\hline Oktober & Rp. $\quad 3.341 .000$ \\
\hline November & Rp. $\quad 3.126 .500$ \\
\hline Desember & Rp. $\quad 3.876 .500$ \\
\hline Januari 2012 & Rp. 7.558 .500 \\
\hline Februari & Rp. $\quad 4.722 .500$ \\
\hline Maret & Rp. $\quad 5.044 .500$ \\
\hline April & Rp. $\quad 5.584 .500$ \\
\hline Mei & Rp. $\quad 4.231 .500$ \\
\hline Juni & Rp. $\quad 5.756 .500$ \\
\hline Juli & Rp. $\quad 5.701 .500$ \\
\hline Jumlah & Rp. 51.033 .000 \\
\hline \multicolumn{2}{|c|}{ Sumber : Laporan keuangan Madrasah AL-Burhaniyah 2011/2012 } \\
\hline \multicolumn{2}{|c|}{ Tabel 10. Penerimaan Madrasah Diniyah Al Burhaniyah Tahun 2012/2013 } \\
\hline Bulan & Penerimaan \\
\hline September 2012 & Rp. $\quad 5.471 .500$ \\
\hline Oktober & Rp. $\quad 5.759 .000$ \\
\hline November & Rp. $\quad 4.534 .000$ \\
\hline Desember & Rp. $\quad 5.172 .000$ \\
\hline Januari 2013 & Rp. $\quad 4.779 .000$ \\
\hline Februari & Rp. $\quad 3.770 .000$ \\
\hline Maret & Rp. $\quad 4.970 .000$ \\
\hline
\end{tabular}


Tabel 10. Lanjutan

\begin{tabular}{llr}
\hline & Bulan & \multicolumn{2}{c}{ Penerimaan } \\
\hline April & Rp. & 4.789 .000 \\
Mei & Rp. & 4.030 .000 \\
Juni & Rp. & 5.818 .000 \\
Juli & Rp. & 11.127 .000 \\
\hline \multicolumn{2}{c}{ Sup. } & 60.219 .500 \\
\hline
\end{tabular}

Tabel 11. Penerimaan Madrasah Diniyah Al Burhaniyah Tahun 2013/2014

\begin{tabular}{|c|c|}
\hline Bulan & Penerimaan \\
\hline September 2013 & Rp. $\quad 6.169 .000$ \\
\hline Oktober & Rp. $\quad 5.509 .500$ \\
\hline November & Rp. $\quad 7.259 .500$ \\
\hline Desember & Rp. $\quad 8.424 .500$ \\
\hline Januari 2014 & Rp. $\quad 5.279 .000$ \\
\hline Februari & Rp. $\quad 4.758 .000$ \\
\hline Maret & Rp. $\quad 3.818 .000$ \\
\hline April & Rp. $\quad 5.178 .000$ \\
\hline Mei & Rp. $\quad 4.759 .000$ \\
\hline Juni & Rp. $\quad 6.014 .000$ \\
\hline Juli & Rp. $\quad 7.283 .000$ \\
\hline Jumlah & $\mathrm{Rp} \quad 64.451 .500$ \\
\hline
\end{tabular}

Sumber: Laporan keuangan Madrasah AL-Burhaniyah 2013/2014

Setelah diperoleh jumlah penerimaan dalam satu tahun, kemudian dihitung prosentase dasar alokasinya untuk masing-masing jenis biaya. Kemudian menentukan cost driver serta menghitung pula berapa kali jumlah konsumsinya atau berapa kali setiap jenis biaya dikeluarkan dalam satu tahun. Selanjutnya menghitung besarnya prosentase dari cost driver dalam rupiah sebagai biaya yang akan dibebankan. Perhitungan uang syariah untuk setiap siswa per bulannya dengan metode ABC diperlihatkan dengan Tabel 12.

Tabel 12. Perhitungan Uang Syariah Madrasah Diniyah Al Burhaniyah Tahun 2011/2012.

\begin{tabular}{|c|c|c|c|c|}
\hline Jenis Aktivitas & Dasar Alokasi') & $\begin{array}{c}\text { Cost } \\
\left.\text { driver }^{* *}\right)\end{array}$ & & $\begin{array}{l}\text { Biaya } \\
\left.\text { bankan }{ }^{* * *}\right)\end{array}$ \\
\hline Biaya honor guru & $27 \%$ & 1.152 jam & Rp. & 13.778 .910 \\
\hline Perawatan sarana prasarana & 2,9\% dari pendapatan & 12 lokal & Rp. & 1.479 .957 \\
\hline Administrasi kelas & $0,6 \%$ dari pendapatan & 8 kelas & Rp. & 306.198 \\
\hline Biaya sosial & $0,2 \%$ dari pendapatan & $1 \mathrm{x}$ setahun & Rp. & 102.066 \\
\hline Evaluasi dan laporan & $1,9 \%$ dari pendapatan & 162 siswa & $\mathrm{Rp}$. & 969.627 \\
\hline Biaya listrik & Direct tracing & $60 \mathrm{KWH}$ & Rp. & 50.000 \\
\hline Biaya telepon & Direct tracing & - & & \\
\hline Biaya rapat & $0,5 \%$ dari pendapatan & $6 x$ setahun & Rp. & 255.165 \\
\hline Biaya kegiatan & $4,8 \%$ dari pendapatan & $3 x$ setahun & Rp. & 2.449 .584 \\
\hline Biaya administrasi madrasah & & - & & \\
\hline Jumlah & & & Rp. & 19.341 .557 \\
\hline
\end{tabular}


Tabel 13. Perhitungan Uang Syariah Madrasah Diniyah Al Burhaniyah Tahun 2012/2013.

\begin{tabular}{llllr}
\hline \multicolumn{1}{c}{ Jenis Biaya } & \multicolumn{1}{c}{ Dasar Alokasi*) } & \multicolumn{1}{c}{$\begin{array}{c}\text { Cost } \\
\text { driver }\end{array}$} & \multicolumn{2}{c}{$\begin{array}{c}\text { Biaya } \\
\text { dibebankan }\end{array}$} \\
\hline Biaya honor guru & $37 \%$ & 1.152 jam & Rp. & 22.435 .000 \\
Perawatan sarana prasarana & $2,1 \%$ dari pendapatan & 12 lokal & Rp. & 1.264 .610 \\
Administrasi kelas & 0,4\% dari pendapatan & 8 kelas & Rp. & 240.878 \\
Biaya sosial & $1,3 \%$ dari pendapatan & 4x setahun & Rp. & 782.854 \\
Evaluasi dan laporan & $1,8 \%$ dari pendapatan & 174 siswa & Rp. & 1.083 .951 \\
Biaya listrik & Direct tracing & $120 \mathrm{KWH}$ & Rp. & 100.000 \\
Biaya telepon & Direct tracing & - & & - \\
Biaya rapat & 2,9\% dari pendapatan & 4x setahun & Rp. & 1.746 .366 \\
Biaya kegiatan & $3,7 \%$ dari pendapatan & 4x setahun & Rp. & 2.228 .122 \\
Biaya administrasi madrasah & 0,8\% dari pendapatan & 1x setahun & Rp. & 481.756 \\
\hline \multicolumn{1}{c}{ Jumlah } & & & Rp. & 30.363 .537 \\
\hline
\end{tabular}

Tabel 14. Perhitungan Uang Syariah Madrasah Diniyah Al Burhaniyah Tahun 2013/2014.

\begin{tabular}{|c|c|c|c|}
\hline Jenis Biaya & Dasar Alokasii) & $\begin{array}{c}\text { Cost } \\
\left.\text { driver }^{* *}\right)\end{array}$ & $\begin{array}{c}\text { Biaya } \\
\left.\text { dibebankan }{ }^{* * *}\right)\end{array}$ \\
\hline Biaya honor guru & Direct tracing & $1.152 \mathrm{jam}$ & Rp. $\quad 20.845 .000$ \\
\hline Perawatan sarana prasarana & $3,3 \%$ dari pendapatan & 12 lokal & 2.126 .900 \\
\hline Administrasi kelas & $0,7 \%$ dari pendapatan & 7 kelas & 451.161 \\
\hline Biaya sosial & $1,2 \%$ dari pendapatan & $5 x$ setahun & 773.418 \\
\hline Evaluasi dan laporan & $2,4 \%$ dari pendapatan & 170 siswa & 1.546 .836 \\
\hline Biaya listrik & Direct tracing & $59,5 \mathrm{KWH}$ & 50.000 \\
\hline Biaya telepon & Direct tracing & Voucher & 50.000 \\
\hline Biaya rapat & $0,3 \%$ dari pendapatan & $3 x$ setahun & 193.355 \\
\hline Biaya kegiatan & $4,2 \%$ dari pendapatan & $4 \mathrm{x}$ setahun & 2.706 .963 \\
\hline Biaya administrasi madrasah & $0,5 \%$ dari pendapatan & $2 x$ setahun & 322.258 \\
\hline Jumlah & & & 29.065 .891 \\
\hline
\end{tabular}

Keterangan :

*) Jumlah biaya setiap jenis pengeluaran dibagi dengan jumlah pendapatan

${ }^{* *}$ ) Menghitung berapa kali biaya dikeluarkan berdasarkan data laporan keuangan yang ada ${ }^{* * *}$ ) Menghitung besarnya \% dari dasar alokasi

Jumlah yang dibebankan inilah yang harus dibayarkan siswa sebagai biaya pendidikan atau uang syariah yang harus dibayarkan setiap bulannya. Perhitungan tarif uang syariah tersebut disajikan dalam Tabel 15.

Tabel 15. Perhitungan Tarif Uang Syariah Dengan Metode ABC Tahun 2011/2012.

\begin{tabular}{cccc}
\hline Jumlah siswa & Biaya & \multicolumn{2}{c}{ Uang syariah (dibagi jumlah siswa) } \\
\cline { 3 - 4 } & dibebankan & Per tahun & Per bulan \\
\hline 162 & Rp. 19.341.557 & Rp. 119.392 & Rp. 9.949 \\
\hline \multirow{3}{*}{ Tabel 16. Perhitungan Tarif Uang Syariah Dengan } & Metode ABC Tahun 2012/2013. \\
\hline Jumlah siswa & Biaya & Uang syariah (dibagi jumlah siswa) \\
\cline { 2 - 4 } & dibebankan & Per tahun & Per bulan \\
\hline 174 & Rp. 30.363.537 & Rp. 174.503 & Rp. 14.542 \\
\hline
\end{tabular}


Tabel 17. Perhitungan Tarif Uang Syariah Dengan Metode ABC Tahun 2013/2014.

\begin{tabular}{cccc}
\hline Jumlah siswa & Biaya & \multicolumn{2}{c}{ Uang syariah (dibagi jumlah siswa) } \\
& dibebankan & Per tahun & Per bulan \\
\hline 170 & Rp. 29.065.891 & Rp. 170.976 & Rp. 14.248 \\
\hline
\end{tabular}

Hasil perhitungan biaya pendidikan dengan metode tradisional dan metode $A B C$ diperoleh angka yang hampir sama karena selisihnya kecil. Hasil penelitian ini berbeda dengan penelitian sebelumnya yang dilakukan di institusi pendidikan tinggi. Penelitian tersebut dilakukan oleh Kania (2013) yang memperoleh unit cost biaya pendidikan yang dihitung dengan metode tradisional memiliki hasil yang berbeda dengan unit cost yang dihitung dengan metode $A B C$. Metode $A B C$ menghasilkan unit cost yang lebih tinggi jika dibandingkan dengan metode tradisional. Besarnya perbedaan ini disebabkan karena jumlah kerja yang besar pada bagian kesiswaan. Meskipun, unit cost akan lebih rendah jika jumlah siswa semakin banyak.

Pada penelitian ini biaya pendidikan per siswa per bulan di Madrasah Diniyah Al Burhaniyah dengan metode tradisional dan metode $A B C$ hampir sama. Selisih biaya yang dihasilkan dari kedua metode ini nilainya cukup kecil. Dengan demikian, hasil perhitungan biaya pendidikan di Madrasah Diniyah Al Burhaniyah dengan metode tradisional dan metode ABC tidak jauh berbeda.

Perhitungan yang dilakukan selanjutnya adalah pengukuran value for money yang mencakup efektifitas dan efisiensi pengelolaan Madrasah Diniyah.

1. Perhitungan efektifitas

Tingkat efektifitas = (realisasi penerimaan/target penerimaan) $\times 100 \%$

a. Perhitungan efektivitas anggaran biaya untuk tahun ajaran 2011/2012

Target penerimaan $=162 \times$ Rp. $10.000 \times 12$ bulan $=$ Rp. 19.440 .000

Tingkat efektivitas $=($ Rp. 51.033.000/Rp. 19.440.000) $\times 100 \%=263 \%$

b. Perhitungan efektivitas anggaran biaya untuk tahun ajaran 2012/2013

Target penerimaan $=174 \times$ Rp. $15.000 \times 12$ bulan $=$ Rp. 31.320 .000

Tingkat efektivitas $=($ Rp. 60.219.500/Rp. 31.320.000) $\times 100 \%=192 \%$

C. Perhitungan efektivitas anggaran biaya untuk tahun ajaran $2013 / 2014$

Target penerimaan $\quad=170 \times$ Rp. $15.000 \times 12$ bulan $=$ Rp. 30.600 .000

Tingkat efektivitas $=($ Rp. $64.451 .500 /$ Rp. 30.600 .000$) \times 100 \%=211 \%$

Selain itu, efektivitas pengelolaan juga dapat dilihat dari faktor:

a. Layanan belajar dilihat dari ketersediaan jumlah tenaga pendidik yang sesuai dengan kebutuhan jumlah siswa.

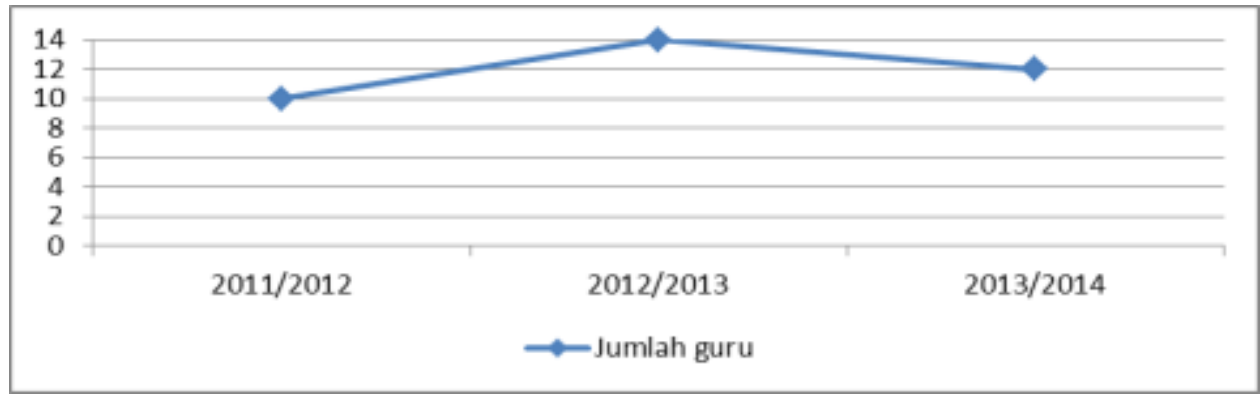

Gambar 1. Jumlah Guru Madrasah Diniyah Al-Burhaniyah (dalam 3 tahun) 
b. Sarana-prasarana dilihat dari ketersediaan fasilitas penunjang yang sesuai dengan kebutuhan dalam proses belajar mengajar.

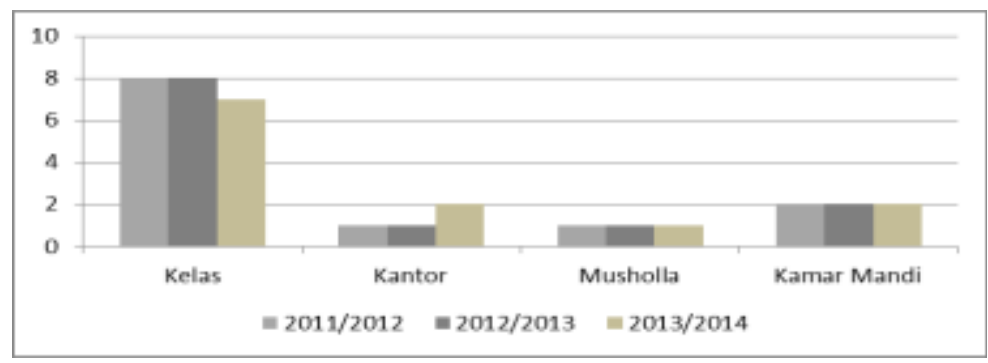

Gambar 2. Grafik Jumlah Gedung Madrasah Diniyah AlBurhaniyah (dalam 3 tahun)

c. Pembiayaan dilihat dari kesesuaian biaya pendidikan yang ditetapkan pada setiap tahun ajaran dengan semua kebutuhan aktivitas pendidikan di Madrasah Diniyah Al-Burhaniyah dan dilihat pula dari peningkatan penerimaan.

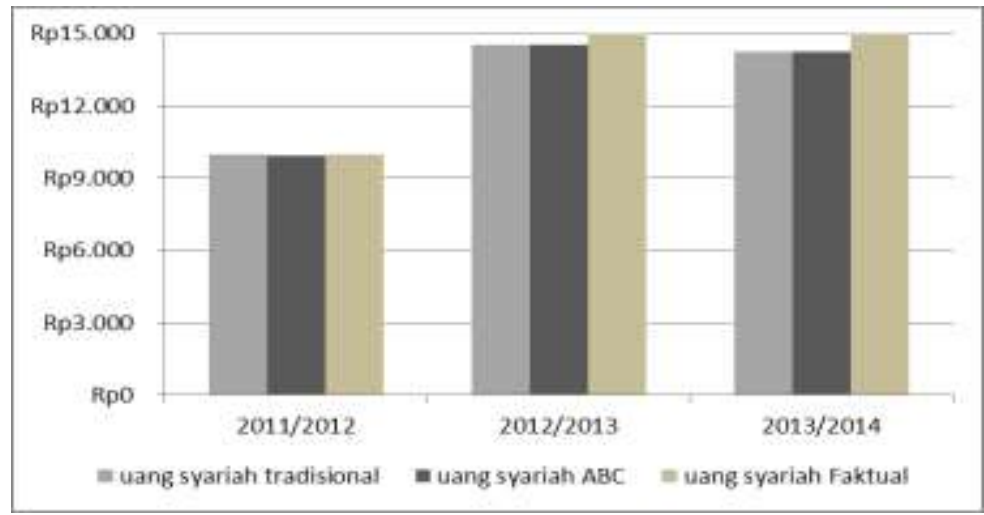

Gambar 3. Uang Syariah per Siswa per Bulan Madrasah Diniyah Al-Burhaniyah (dalam 3 Tahun)

d. Partisipasi masyarakat dilihat dari peningkatan jumlah peserta didik.

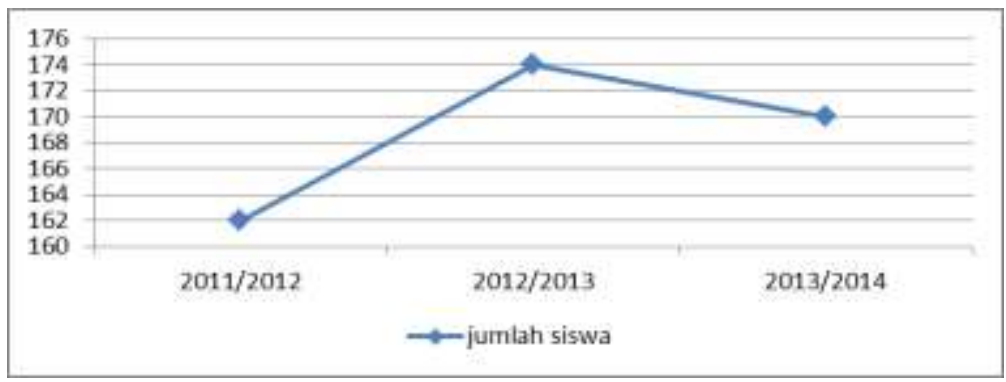

Gambar 4. Jumlah Siswa Madrasah Diniyah Al-Burhaniyah (dalam 3 tahun) 
2. Perhitungan efisiensi

Tingkat efisiensi $=$ (keluaran riil/anggaran) $\times 100 \%$

Tabel 21. Perhitungan Efisiensi Untuk Jumlah Biaya Pendidikan pada Metode Tradisional

\begin{tabular}{ccccc}
\hline Tahun & Pengeluaran & Anggaran & \% fisiensi & Kriteria \\
\hline $2011 / 2012$ & Rp. 19.396 .000 & Rp. 51.033 .000 & 38 & Sangat efisien \\
$2012 / 2013$ & Rp. 30.382 .600 & Rp. 60.219 .500 & 51 & Sangat efisien \\
$2013 / 2014$ & Rp. 29.109 .000 & Rp. 64.451 .500 & 45,2 & Sangat efisien \\
\hline
\end{tabular}

Tabel 22. Perhitungan Efisiensi Untuk Jumlah Biaya Pendidikan pada Metode ABC

\begin{tabular}{ccccc}
\hline Tahun & Pengeluaran & Anggaran & \% fisiensi & Kriteria \\
\hline $2011 / 2012$ & Rp. 19.341 .557 & Rp. 51.033 .000 & 37,9 & Sangat efisien \\
$2012 / 2013$ & Rp. 30.363.537 & Rp. 60.219 .500 & 50 & Sangat efisien \\
$2013 / 2014$ & Rp. 29.065 .891 & Rp. 64.451 .500 & 45,1 & Sangat efisien \\
\hline
\end{tabular}

Apabila dilihat dari nilai prosentase efisiensinya, terdapat perbedaan angka prosentase untuk setiap tahun ajaran. Prosentase efisiensi tertinggi ada pada tahun ajaran 2011/2012 yang mencapai angka 38\%, dilanjutkan tahun ajaran 2013/2014 sebesar 45\%, dan yang terakhir tahun 2012/2013 dengan prosentase $50 \%$. Perbedaan prosentase ini diharapkan menjadi masukan bagi pengelola Madrasah Diniyah Al-Burhaniyah untuk memperbaiki sistem manajemennya hingga bisa meningkatkan tingkat efisiensinya lagi, seperti yang sudah dilaksanakan pada tahun ajaran 2011/2012. Diharapkan penelitian ini dapat memberi informasi yang bermanfaat untuk pengembangan pendidikan di Madrasah Diniyah Al-Burhaniyah. Oleh sebab itu, perlu dilakukan perbaikan-perbaikan strategi dalam manejemennya untuk memperloleh hasil yang lebih baik dari sebelumnya.

Berdasarkan perhitungan efektivitas dan efisiensi pengelolaan Madrasah Diniyah AlBurhaniyah untuk tahun ajaran 2011/2012 hingga 2013/2014 ada beberapa faktor yang dapat digunakan sebagai tambahan informasi dan masukan untuk memperbaiki manajemen yang sudah ada. Faktor-faktor tersebut meliputi:

1. Layanan belajar

Layanan belajar yang disediakan Madrasah Diniyah Al-Burhaniyah ini ketersediaan jumlah tenaga pendidik yang mencukupi kebutuhan jumlah siswa. Madrasah Diniyah Al-Burhaniyah yang jumlah siswanya masih sedikit, akan lebih baik apabila pengelola memaksimalkan tenaga pendidik yang ada. Artinya, jika tidak ada penambahan jumlah murid yang besar, maka jumlah guru yang ada sekarang sudah cukup tanpa perlu penambahan tenaga pengajar lagi. Jika pemaksimalan SDM guru ini sudah dapat dilakukan, maka akan berdampak pada pemberian kompensasi dan tunjangan yang layak bagi kehidupan guru tersebut. Pemberian kompensasi dan tunjangan yang layak ini tentunya akan memotivasi setiap guru untuk meningkatkan kualitasnya dalam memberikan layanan belajar bagi para peserta didiknya.

2. Sarana-prasarana

Fasilitas sarana kelas ataupun penunjang lainnya di Madrasah Diniyah Al-Burhaniyah ini masih dibilang terbatas untuk menuju penyelenggaraan pendidikan yang berkualitas. Pengelola Madrasah Diniyah Al-Burhaniyah diharapkan mampu mengembangkan kualitas pendidikannya ke arah yang lebih baik dengan menambah sarana penunjang kegiatan belajar. Penambahan 
sarana tersebut diantaranya adalah penyediaan sarana perpustakaan untuk menambah buku pelajaran dan referensi belajar siswa. Selain itu, juga pengembangan proses belajar dengan multimedia untuk meningkatkan minat belajar siswa. Di zaman yang sarat dengan era gadget saat ini akan membuat peserta didik lebih tertarik belajar dengan menggunakan media IT yang canggih jika dibandingkan dengan kegiatan belajar yang konvensional dimana guru sebagai center of learning. Tentunya penambahan sarana ini harus ditunjang dengan sumber pendanaan yang cukup. Oleh sebab itu, pengelola Madrasah Diniyah Al-Burhaniyah harus berupaya sedemikian rupa untuk bisa menambah sumber pendanaannya.

3. Pembiayaan

Pengelola Madrasah Diniyah Al-Burhaniyah diharapkan lebih baik lagi dalam menyusun anggaran biaya untuk mendanai segala kegiatan pendidikan yang ada. Selain itu, juga harus lebih cermat dalam mengalokasikan biaya untuk suatu kegiatan. Sehingga, dapat dicapai efektivitas dan efisiensi biaya untuk mencapai tujuan sebagai output yang diharapkan. Alokasi dana untuk kegiatan dan sarana prasarana ini penting untuk ditingkatkan karena melalui kegiatan pendidikan, lomba, maupun pengembangan SDM guru karena dapat meningkatkan kualitas pembelajaran di Madrasah Diniyah Al-Burhaniyah. Kemudian ditunjang dengan pemenuhan sarana-prasarana yang memadai.

4. Partisipasi masyarakat

Peningkatan partisispasi masyarakat untuk mengikutsertakan putra-putrinya menjadi peserta didik Madrasah Diniyah Al- adalah dengan melakukan berbagai strategi promosi yang bisa menarik minat konsumen.Strategi promosi tersebut dapat dilakukan dengan mengadakan acara openhouse maupun pengajian umum yang selama ini diadakan oleh Madrasah Diniyah AlBurhaniyah. Terlebih lagi sudah ada anggaran untuk kegiatan sosial yang digunakan untuk mendanai biaya-biaya yang berhubungan dengan interaksi Madrasah Diniyah Al-Burhaniyah dengan masyarakat sekitar. Apabila partisipasi masyarakata naik, maka jumlah siswa pun akan bertambah yang berdampak pada peningkatan sumber dana yang dapat dimanfaatkan untuk kemajuan Madrasah Diniyah Al-Burhaniyah.

Dari beberapa implikasi untuk pengelolaan Madrasash Diniyah Al-Burhaniyah tersebut diharapkan dapat menjadi informasi yang bermanfaat untuk pengembangan pendidikan di Madrasah Diniyah Al-Burhaniyah untuk bisa lebih baik lagi. Mengingat Madrasah Diniyah Al-Burhaniyah sudah memiliki modal yang cukup untuk berkembang lebih besar lagi. Sehingga, perlu dilakukan perbaikanperbaikan strategi dalam manejemennya untuk memperloleh hasil yang lebih baik dari sebelumnya dalam rangka kemajuan Madrasah Diniyah. Terlebih, saat ini sudah ada program akreditasi Madrasah Diniyah yang telah disosialisasikan oleh Departemen Agama. Sehingga, keberadaan Madrasah Diniyah ini sudah diakui keberadaannnya untuk lebih bisa dimajukan lagi kualitasnya. Baik dari segi kualitas manajemen maupun kurikulum pendidikannya.

\section{SIMPULAN}

Berdasarkan penelitian tentang perhitungan biaya pendidikan di Madrasah Diniyah AlBurhaniyah dapat disimpulkan bahwa:

1. Biaya pendidikan di Madrasah Diniyah Al Burhaniyah untuk setiap siswa per bulan dengan metode tradisional untuk tahun 2011/2012, 2012/2013 hingga 2013/2014 mengalami perubahan dari Rp. 9.977, Rp.14.551 kemudian menjadi Rp14.269. 
2. Biaya pendidikan di Madrasah Diniyah Al Burhaniyah untuk setiap siswa per bulan dengan metode Activity Based Costing System (ABC) untuk tahun 2011/2012, 2012/2013 hingga 2013/2014 terdapat perubahan. Dari Rp. 9.949 lalu Rp.14.542 menjadi Rp. 14.248. Biaya yang diperoleh dengan metode $A B C$ ini hampir sama dengan perolehan metode tradisional.

3. Pengelolaan Madrasah Diniyah Al-Burhaniyah untuk tahun 2011/2012 hingga 2013/2014 sudah efektif dan efisien. Faktor efektif dan efisien tersebut dapat dilihat dari layanan belajar, saranaprasarana, pembiayaan dan partisipasi masyarakat.

\section{REFERENSI}

Amir, A.M., Sofiah Md.A., Ruhanita M. \& Azlina A. (2012). Determination of educational cost in public university - A modified activity based approach. World journal of social sciences, vol. 2, No. 2, March 2012, 34-48.

Badan Standar Nasional Pendidikan. (2006). Standar biaya pendidikan: Biaya operasi sekolah dasar. Jakarta: BSNP.

Blotcher, Edward J., David E. S. \& Gary C. (2011). Manajemen biaya: Penekanan strategis. Jakarta: Salemba Empat.

Departemen Pendidikan Nasional. (2004). Undang-undang Republik Indonesia Nomor 20 Tahun 2003.

Juanda, Ahmad \& Lestari, N.V. (2012). Analisis perhitungan biaya satuan (unit cost) Penyelenggaraan pendidikan kedokteran (Studi kasus pada fakultas kedokteran Universitas Muhammadiyah Malang). Jurnal review akuntansi dan keuangan, vol.2, No.1, 2012, 227-241.

Kania, Beeta D. (2013). Using the ABC method into management system of educational services in higher education. Human and social sciences at the common conference, No 22, November 2013, 54-56.

Krishnan, Anbalagan. (2006). An application of activity based costing in higher learning institution: A local case study. Contemporary management research, vol. 2, No 2, September 2006, 75-90.

Mardiasmo. (2005). Akuntansi sektor publik. Yogyakarta: Andi Yogyakarta.

Prasetyo, Joko. (2012). Transparansi dalam penentuan besaran biaya pendidikan per siswa SD negeri sebagai produk pelayanan publik di Kab. Bintan Prov. Kep. Riau. Makalah. Jogjakarta: Fakultas Ekonomika dan Bisnis Universitas Gadjah Mada.

Ruhupatty, Le Roy \& Ben A. Maguad. (2012). Using the activity-based costing approach to measure the cost of quality in higher education: A faculty perspective. Academic journal article education, vol. 132, No.2, Winter 2015, 1-23. 